\title{
Analysis of Health Sector Gender Equality and Social Inclusion Strategy 2009 of Nepal
}

Mahara GB, ${ }^{1}$ Dhital SR ${ }^{2}$

\author{
${ }^{1}$ Department of Community Medicine \\ National Academy of Medical Science, \\ Bir Hospital, Kathmandu, Nepal \\ ${ }^{2}$ Green Institute of Science and Technology \\ Tulsipur-6, Dang, Nepal
}

\section{Corresponding Author}

Gehendra Bahadur Mahara

Department of Community Medicine

National Academy of Medical Science

Bir Hospital, Kathmandu, Nepal

E-mail: gbmahara@gmail.com

\section{Citation}

Mahara GB, Dhital SR. Analysis of Health Sector Gender Equality and Social Inclusion Strategy 2009 of Nepal. Kathmandu Univ Med J 2014;46(2):157-60.

\begin{abstract}
The policy on gender equality and social inclusion (GESI) in health sector of Nepal is formulated in 2009 targeting toward poor, vulnerable, marginalized social and ethnic groups. Gender inequality and social discrimination are a social problem that affect on individual health finally. The main objective of this paper is to critically analysis and evaluates the Government's strategy on health sector gender equality and social inclusion in Nepal. We collected published and unpublished information assessing the public health, policy analysis and research needs from different sources. A different policy approaches for the analysis and evaluation of GESI strategies is applied in this paper. Universal education, community participation, individual, group and mass communication approaches, and social capital are the key aspects of effective implementation of policy at target levels.
\end{abstract}

\section{KEYWORDS}

Community participation, gender equality, health, marginalized, policy, social inclusion, social capital.

\section{INTRODUCTION}

Policy analysis is a complex way of knowing existing policy and making it concrete as context base. Gender Equality and Social Inclusion (GESI) is a sensitive issue in public health and it should be effective working in all aspects. The purpose of this article is to critically analysis and evaluates the Nepal Government's strategy on health sector gender equality and social inclusion (GESI)-2009. ${ }^{1}$ The target population of this policy document is as follows: the poor, vulnerable, marginalized social and ethnic groups. This policy is analyzed the strengths, weaknesses and limitations of its goals, the strategies and plans for target groups. The evaluation is done by using evaluation criteria like importance, usefulness along with effectiveness, efficiency, equity and acceptability on the basis of social perspectives theories, principles, models, approaches, guidelines and recommendations.

\section{EVALUATION CRITERIA}

The Marmot review "Fair Society, Healthy Lives" is applied to evaluate the GESI policy because it made recommendations on how a healthy public policy can be effective to reduce health inequalities. ${ }^{2}$ In addition those recommendations are underpinned by the values of social justice, equity, the life course approach and proportionate Universalism principles. The values of social justice are important because it is related to gender, race, religion and ethnic origin of the people of that society to reduce gender inequalities. $^{3}$ The equity is also important to associate the individual net benefit or makes equal opportunities to achieve the health care benefits of society that help to reduce social exclusion. ${ }^{4}$ Furthermore, the life course approach is important because whole or earlier cycle of life events forecast the future mortality and morbidity rates of people. ${ }^{3}$ 
The policy recommendations of Benzeval, et al 1995 is applied for the evaluation of GESI policy. ${ }^{5}$ Because these recommendations have focused on individual lifestyle of people, the social network and community influences, living and working conditions of people, socioeconomic, cultural and environmental factors. These are social determinant factors of health at different levels which affects the health of the population. ${ }^{6}$ The policy should be focused on those social determinants to tackle with health inequalities in society. ${ }^{5}$ This is because if an individual lifestyle is bad as like smoking, alcohol habit then it affects the individual as well as family's health and these risky behaviors of people also affect to the society. Furthermore these behaviors of people depend upon the social and community network such as family, peer groups and community and those factors are also influenced by the economic condition of the people. ${ }^{3}$

The World Health Organization's Adelaide recommendations on Healthy Public Policy is applied to evaluate the GESI policy because, it made recommendations on how to enable the poor, vulnerable, marginalized social and ethnic groups as well as utilize health facilities and become healthy. These recommendations are based on the concept of social justice, the value of health, equity, access and development, supportive environment, development of personal skills, strengthen community action and quality health service. ${ }^{7}$ These are important determinants factors of health inequalities and the policy should be addressed such factors to reduce the health inequalities. ${ }^{3,5}$ To reduce the gender inequalities, the policy should be focused on affecting factors of health inequalities such as; employment, education, structure of family and household, social and economic level. ${ }^{8}$

\section{POLICY ANALYSIS BY USING EVALUATION CRITERIA}

The aim of this GESI policy was to reduce gender inequalities and promote social inclusion by providing education, information and communication as well as better access and quality of health services to the target population. Nepal has gender inequality in the health sector due to the patriarchal society, traditions and cultural beliefs. ${ }^{9}$ This GESI policy also speaks to reduce the patriarchy and gender discrimination by empowering the target groups through the education, information and communication. It is the strength of this policy because patriaticial society believes that women are subordinate and this belief is a barrier to utilise the health service for the women., ${ }^{9,10}$ People still have been receiving health services by traditional healers (traditional treatment system e.g. Dhami, Jhankri, Baidhya) in the village such as Jumla, Humla, Bajura districts of Nepal. ${ }^{9}$ The male dominated society do not have permission to utilise health services to the women. Traditional healers can be found easily in the society and also they provide free service to the people. In addition, people trust them rather than the modern health care system and health workers. ${ }^{11}$
So that there should be free and quality health service necessary to reduce health inequalities.

This GESI policy is not focusing the gender training to schools and colleges to tackle the discriminatory patriarchy and reduce social exclusion through students and teachers. ${ }^{12}$ This is a limitation of GESI policy because schools and colleges are an effective place to transfer the education and knowledge to the people. ${ }^{12}$ So that the policy should be focused on gender trainings to tackle the health inequalities and reduce the gender inequalities. ${ }^{13}$

Furthermore GESI policy is giving emphasis to make aware the target groups through empowerment by providing employment opportunity, encouraging them through participation in the health programs and provide quality and accessible health service to reduce the gender inequalities. ${ }^{9}$ This is good because the target groups can be empowered by participating in health programs in the community. ${ }^{14}$ The strategy of WHO health for all 2000, Ottawa charter and Jakarta Conferences also highlighted the importance of empowering the target groups and community member by participating in health program to reduce health inequalities..$^{15,16}$

The GESI policy has not followed the Marmot recommendation of The life course approach to help to reduce health inequalities. This can be considered as a limitation of the policy, because the life course approach shows that ill health, wealth and poverty are accumulated over an individual's course of life even from before birth. ${ }^{1}$ The future of the child depends upon the parental income, education and housing, food quality and employment. ${ }^{3}$ The Marmot has given emphasis to enable the child, young people and adult, to create fair employment, maintain the healthy and standard living. The recommendations for the GESI policy is to be focused on a life course approach by Nepal Government to reduce inequalities and improve health and well-being of the target groups.

The GESI policy has focused on tackling inequalities in health a review policy of Benzeval et al. (1995) to decrease the gender inequalities in the health sector of Nepal. This policy has addressed in the working plan of policy for example; change individual lifestyle or behavior, influencing factors of society, living and working conditions, socioeconomic factors, cultural and environmental factors and these are determinant factors of health inequalities. ${ }^{6,9}$ This is the strength of this policy, because the third level of tackling inequalities by Benzeval et al explained that good housing, sanitation, uncontaminated food supplies, environment of work places and quality health services should be addressed to tackling the health inequalities. ${ }^{5}$ Likewise work and employment are especially important in gender and health of people because quality of social life depends upon the income of the people. ${ }^{8}$ Employment and work can help to reduce inequalities in health because income is a main determinant factor of health improvement in society. ${ }^{14}$ 
The GESI policy is used as a review policy recommendation of Benzeval et al such as strengthening individual and communities, increase the social capital and reduce the gender inequalities and social exclusion in the health sector of Nepal. ${ }^{5}$ It also has explained that the behaviour change training for individual, awareness programs to empower and reduce discrimination, making healthy environment, increase the access of health services and making a network between service provider and target groups. ${ }^{9}$ This is the strength of this policy because social capital bonds and makes close relations between groups, social institutions as well as individual in a community. ${ }^{17}$ This bond helps to reduce the health inequalities in society. ${ }^{18}$ Similarly, social capital is the value of social networking, neighborhood attachment civic participation. ${ }^{13}$ It helps to protect the health of people and also help the mitigate the effect of poor social factors e.g., quantifiable effects, lower crime rates, greater level of income, improve child welfare, lower rates of child abuse and enhanced economic achievement. ${ }^{19,20}$

In addition, social capital develops the capacity building of people, community development, community network, social cohesion and social inclusion in society. ${ }^{21}$ Wilkinson again explains that if social capital increased in the society then the pre-occupation with materialistic values is increased and if social capital decrease then the community relationship falls to the health inequalities and more exclusion. ${ }^{21}$ In addition Pilkington is also suggested that social capital could help to tackle health inequalities more efficiently at a community level. ${ }^{22}$

This GESI policy has given emphasis of the guidelines of Adelaide recommendations for healthy public policy high priority to tackling inequalities to underprivileged and vulnerable groups. ${ }^{7}$ The GESI policy is focusing to the unique culture of indigenous peoples, ethnic minorities, underprivileged, vulnerable, socially and educationally disadvantaged people. ${ }^{9}$ This is a strength of this policy because information, education and communication make it possible to utilise the health service such as; mass media communication through pamphlets, leaflets, posters, banners, interpersonal communication (group discussion, meeting, counselling), and skill development training to the target groups to reduce health inequalities. ${ }^{14}$ But these mass media and communication are not enough because it is difficult to convey the complex information and teach the skills like sex education in the strong attitude, traditional believes and religious society. ${ }^{3}$

Furthermore the WHO, Ottawa Charter has also given emphasis on health literacy of people. ${ }^{15}$ It includes the knowledge, personal skills and essential health education (related to risk factors of health and behaviour), health care system (with quality, acceptable and accessible) to the whole population of society and also proper utilise it by target groups. ${ }^{14}$ Similarly, several research studies have also shown that the literacy of women is less than men and due to that they are not utilizing available health services in
Nepal. ${ }^{11,23,25}$ Because Nepal is an underdeveloped country having most of the parts hills and mountains and human development index (HDI) ranked 157 that is very low compared to other developed and developing countries. ${ }^{26,27}$ In this context radio is very effective communication media for example "cut your coat according to your cloth" was broadcast nationally by Radio Nepal during Dec 1995 to Dec 1996 (57 episodes) in Nepali language. It was about family planning and contraceptive use. ${ }^{14}$ But still it is not fully possible to empower the target groups due to having a poor country, geographical distribution and strong conservative beliefs. It may be due to the non-established the political situation and less educational attainment in the country. Even though this GESI policy is trying to reduce the gender inequalities and social exclusion in the target groups by addressing the social determinant factors of health.

\section{CONCLUSION AND RECOMMENDATIONS}

The GESI policy is used WHO recommendations for healthy public policy, Marmot review of 'Fair Society, Healthy Lives' and a review action policy of Benveval et al (1995) to reduce inequalities in health sector in Nepal. The policy has been focused on social determinant factors as well as demographic factors of health to tackle the health inequalities. It is also focused to empower the target groups by providing health education, information, communication, skill training and employment opportunity as well as quality and accessible health services to achieve the goals. These were the strengths of policy. However the GESI policy didn't focus on the life course approach of the Marmot review and gender training in school and college to reduce health inequalities which are the limitations of policy.

Overall this GESI policy 2009 is high-quality but still need to concentrate on the life course of Marmot review, WHO guidelines and gender education in school or college to reduce gender discrimination. Because Nepal is an underdeveloped country having diversity of caste, religions, traditions and conservative believe. Therefore the policy should be focused on those factors to reduce the gender inequalities in health sector of Nepal.

\section{ACKNOWLEDGEMENT}

We are highly gratitude to the Principal Lecturer Jean Brant and my friend Mary Owolaby (University of Wolverhampton United Kingdom) and friends for their active role in providing necessities reference materials and editing this manuscript. We have also thanks to Madhu Koirala, the University of Southern Denmark, the unit for Health Promotion research and Dr. Padam Simkhada Sheffield University, UK for their encouragement to write this paper. 


\section{REFERENCES}

1. Government of Nepal, Ministry of Health and Population, Health Sector Gender Equality and Social Inclusion Strategy 2009, Nepal. [Online] [Cited on 15 Dec 2011] 2011. Available on: http://www.rti. org/pubs/30_Nepal_HealthGenderEquality.pdf

2. Marmot M. Review into health inequalities in England "Fair Society, Healthy Lives'. [Cited on 09 Jan 2012] 2010. Available at: www. marmotreview.org

3. Naidoo J, Wills J. Foundations for Health Promotion. 3nd Ed. London: ELSEVIER Ltd, UK; 2009.

4. Baggott R. Public Health, Policy and Politics. Hampshire: Palgrave Macmilan, England. 2000.

5. Benzeval M, Whitehead M, Judge K. Tackling Inequalities in Health: An Agenda for Action. London: King's Fund, UK; 1995.

6. Dahlgren G., Whitehead M. Policies and Strategies to Promote Social Equity in Health. Stockholm: Institute for future studies, Sweden; 1991.

7. World Health Organization. Adelaide Recommendation on Healthy Public Policy. Geneva, 1988. WHO Publication, Switzerland.

8. Annandale E, Hunt K. Gender Inequalities in Health. 1st Publication. Buckingham: Open University Press, UK;2000.

9. Ministry of Health and Population Nepal, Policies and Strategies of Health Development, Care Guidelines. Kathmandu, Nepal;2011.

10. Barry AM, Yuill C. Understanding the sociology of Health. 2nd Ed. London: SAGE Publication, UK;2008.

11. Simkhada B, Van Teijlingen ER, Porter M, Simkhada P. (2006) Major Problem and Key Issues in Maternal Health in Nepal. Kathmandu University Medical Journal 2006;14(4): 258-263.

12. United Nation Population Funds. Gender Equality and Empowerment of Women in Nepal. [Cited on 08 March 2012] (Online), 2007. Available at: http://nepal.unfpa.org/pdf/Gender\%20Equality.pdf

13. Scriven A, Garman S. Public Health: Social Context and Action. Berkshire: Open University Press. UK;2007.

14. Naidoo J, Wills J. Public Health and Health Promotion, Developing Practice. 2nd Ed. London: ELSEVIER Ltd, UK; 2005.

15. World Health Organization. Ottawa Charter of Health promotion. Geneva. WHO Publication, Switzerland; 1986.
16. World Health Organization. Jakarta Declaration of Health promotion. Geneva, WHO Publication, Switzerland;1997.

17. Putnam R. Bowling Alone: The Collapse and Revival of American Community. New York: Simon and Schuster, USA; 2000.

18. Kunitz SJ. Social Capital and Health, British Medical Bulletin 2004;69: 61-73

19. Coleman JS. Social capital in the creation of human capital. American Journal of Sociology 1988; 94: 95-120.

20. Putnam R. Making Democracy Work: Civic Traditions in Modern Italy. Princeton, NJ: Princeton University Press, USA;1993.

21. Wilkinson RG. Unhealthy Society, the Afflictions of Inequality. London: Rutledge, UK 1996.

22. Pilkington P. Social capital and health: measuring and understanding social capital at a local level could help to tackle health inequalities more effectively. J Public Health 2002; 24 (3):156-159.

23. Dhakal S. Maternal Mortality falls in Nepal but inequalities exist. The Lancet 2007370 (9595):1301-1301.

24. Nepal Demographic and Health Survey [online]. 2011. [Cited on 07 Jan 2012] available at: http://www.measuredhs.com

25. CBS. Central Bureau of Statistics, preliminary report of population. Kathmandu, Nepal: (online) [Cited on 07 Dec 2011] 2011.available at: http://www.cbs.gov.np/

26. United Nations Development Program, International Human Development Indicators of Nepal. 2011. [Accessed on 20 March 2012] http://hdrstats.undp.org/en/countries/profiles.

27. WHO. Social Determinants of Health, World Health Organization. (Online) [Cited on 09 Jan 2012] 2011. Available at: http://www.who. int/social_determinants/en/

28. WHO. Social Determinants of Health, World Health Organization. (Online) [Cited on 09 Jan 2012] 2011. Available at: http://www.who. int/social_determinants/en/

29. Wilkinson R, Pickett K. The Sprit Level, Why Equality is better for everyone. London: Penguin Books, UK; 2009 